\title{
Adverse drug reactions monitoring: prospects and impending challenges for pharmacovigilance
}

\author{
Ram Kumar Sahu*, Rajni Yadav, Pushpa Prasad, Amit Roy and Shashikant Chandrakar
}

\begin{abstract}
Pharmacovigilance plays a consequential role in the surveillance of adverse drug reactions, which is provoked by the drugs used to cure diseases. Adverse drug reactions (ADRs) produce detrimental or undesirable effects to the body after administration of drugs. It has been reported that the number of patients dying because of contrary effects of drugs per year increased upto 2.6-fold. Moreover, rates of hospitalization of patients are increasing owing to adverse effects of drugs. Thus, it becomes challengeable for physician, health care providers, WHO and pharmaceutical industries to resolve the associated problem of ADRs. During the clinical trial of a novel drug, it is prominent to explore the dependability of drug. In this review, we documented the details required to identify the ADRs in patients along with reported banned drugs.
\end{abstract}

Keywords: Pharmacovigilance; Adverse drug reactions; Clinical trial

\section{Introduction}

World Health Organization (WHO) defines that adverse drug reactions (ADRs) are noxious and unwanted effects produced by the drug, when it is applied for the ailment of disease or diagnosis (Shukla et al. 2012). The most common examples of drugs that produce ADRs include paracetamol and nimesulide (hepatotoxic effects) (Rehan et al. 2002).

It is a well-known fact that no drug is completely free from side effects. The European commission proclaimed ADRs (Rishi et al. 2012; Rehan et al. 2002) till date are referred in Table 1.

Before executing any new drug in the market, its clinical trial and safety database are validated for the safety profile of the drug. In various countries, whether developed or developing, the issue of ADRs is accepted to effortlessly, and thus it becomes a prime duty to develop awareness among patients about ADRs.

When a novel drug's safety is under process, it is being constantly supervised by pharmacovigilance centres for the identification of adverse effects of the drug, if any (Beard 1992; Mishra and Kumar 2013). According to WHO, pharmacovigilance is a set of practices aiming at the identification, understanding and assessment of risks associate with drugs. Moreover, they take steps to control the adverse effect of drugs. Pharmacovigilance starts from the pre-marketing

* Correspondence: ramsahu79@yahoo.co.in

Columbia Institute of Pharmacy, Tekari, Raipur, CG 493111, India of new drugs and continues through the post-marketing of drugs (Lazarou et al. 1998).

There are a bunch of examples of drugs, which have been detached as well as outlawed from the European market owing to reported adverse effects of drugs. Rosiglitazone holds the first position in the market; other well-known drugs including terfenadine, cisapride, phenylpropanolamine, rofecoxib, cerivastatin, gatifloxacin, cisapride, sibutramine and tegaserod were withdrawn because of their adverse reactions. For every drug in the market, the adverse events, if any, should be inspected in detail, and the facts should be conveyed to the people or public for elucidation of the information (Hampton 2005; Lisa et al. 2003; Lazarou et al. 1998).

In contemplation to supply the news for effective drug use in population, which includes different groups of patients, such as elderly, children and diseased patients, an adequate information regarding drug's adverse effects is required, which is achieved by a successful pharmacovigilance programmes run on that drug (Gupta and Udupa 2011; Santosh and Tragulpiankit 2002).

Pharmacovigilance plays several roles such as recognition, observation, assessment and documentation of drug based problems and understanding the factors producing adverse effects (Ravi Shankar et al. 2006; Rohilla et al. 2012). Here we tried to summarize about ADRs, and how it can be monitored by pharmacovigilance to minimize 
Table 1 ADRs report according to European Commission Impact

\begin{tabular}{ll}
\hline Patient's report & Percentage reported \\
\hline Patients admitted in hospital & $0.3 \%-5 \%$ \\
Patient's death reported & $3.5 \%$ \\
Patient's reported with ADR during & $1.9 \%-6 \%$ \\
their hospital stay & \\
\hline
\end{tabular}

the adverse effects of drugs. Hence, this review will provide adverse events about ADRs along with the complete information of medication errors.

\section{Proclamations of adverse effects of drug}

The USFDA data disclosed that adverse effect of drugs increased almost two times in the endmost decade. It has been noticed that significant sum of patients were pegged out because of fervent adverse effects of drugs. This report has been authenticated in the $10^{\text {th }}$ issue of the Archives of Internal Medicine (Livio et al. 2012; Doheny 2009; Aeries 1995). The number of reports per annum proliferated upto 2.6-fold from 1998 to 2005. In 1998 , the numbers of adverse events proclaimed were 34,966, which increased to 89,842 by 2005 .

The number of drugs in the market producing ADRs is documented in Table 2.

Scientific data indicated that different drugs were banned, and some were detached owing to the adverse effects in patients (Tables 3 and 4).

\section{Documentation of ADRs}

The pharmacovigilance curriculum conveyed worldwide to motivate that all suspected drug-related adverse events should be outlined. It takes interests on reports of the following:

(A) Every adverse effect suspected or occurred by new drugs and drugs of current issue.

(B) Documentation of various drugs that caused ADRs, which include death, life-threatening conditions, disability, hospitalization and congenital abnormalities.

The significant adverse reaction of any drug should be notified within seven days. The other facts related to adverse events should be informed within eight days (Bates et al. 1995; Classen et al. 1997). The ADR form can be collected through any pharmacovigilance centre. The filled ADR form can be submitted to the peripheral pharmacovigilance centre. After reviewing the form, the centre forwards it to the regional centre and after that it is propelled to the zonal centre (Goldman 1998; Palaian et al. 2006; Ravi Shankar et al. 2010). The details are then statistically inspected and forwarded to WHO-Uppsala Monitoring Committee (UMC).

\section{Procedure for reporting ADRs}

It is the first duty of any pharmacovigilance centre to report all suspected adverse events of the drug if found. Information regarding ADRs and the type of ADRs that should be reported are tabulated in Table 5 .

\section{Monitoring of ADRs}

ADR monitoring is spelled out as the practice of continuously monitoring the undesirable effects caused using any drug. Pharmacovigilance plays an imperative impersonation in monitoring ADRs (Hall et al. 1995; Hornbuckle et al. 1999; Juntti and Neuvoren 2002).

It is inherent for pharmaceutical regulators to screen their pharmaceutical products in the market and record if any suspected adverse reactions are identified. ADRs can occur by use of various pharmaceutical products, herbal drugs, cosmetics, medical devices, biological, etc. The introducing of this monitoring procedure intends at warranting that patients receive safe and beneficial medicinal products (Karch and Lasagna 1997).

If any of the adverse events are not stated it may result in noxious and serious effects of remedial products. Thus, properly conducting ADR monitoring programmes will help to reduce the harmful effects of therapeutic products (Kessler 1993).

\section{Benefits of ADR monitoring}

An ADR monitoring and reporting programme can furnish following benefits:

1. It caters information about quality and safety of pharmaceutical products.

2. It initiates risk-management plans.

3. It prevents the predictable adverse effects and helps in measuring ADR incidence.

4. It instructs health care team, patients, pharmacists and nurses about adverse drug effects and creates awareness regarding ADRs.

The main objective of ADR monitoring is to disclose the quality and frequency of ADRs and to identify the risk factors that can cause the adverse reactions (Moore 2001; Murphy and Frigo 1993).

\section{ADR monitoring includes different studies for the identification of adverse events \\ Case reports}

By this method, the unpredictable (bizarre) effects i.e. TYPE-B adverse drug reactions are reported. 
Table 2 List of drugs causing ADRs

\begin{tabular}{|c|c|c|c|c|}
\hline $\begin{array}{l}\text { Marketed } \\
\text { drug }\end{array}$ & Type of dosage form & $\begin{array}{l}\text { Patients } \\
\text { affected }\end{array}$ & Side effects & References \\
\hline Oxycodone & $\begin{array}{l}\text { Tablet- film coated and } \\
\text { extended release }\end{array}$ & $5 \%$ & $\begin{array}{l}\text { Constipation, nausea, somnolence, dizziness, pruritis, } \\
\text { vomiting, sweating, asthenia, dry mouth, headache }\end{array}$ & (Purdue 2009) \\
\hline Fentanyl & IV, patch & $7.9 \%$ & $\begin{array}{l}\text { Skin reactions, respiratory depression, mental changes, } \\
\text { stroke }\end{array}$ & $\begin{array}{l}\text { (Pasero 2005; Mohammed } \\
\text { 2012) (Peng and Sandler } \\
\text { 1999, Prommer 2009) }\end{array}$ \\
\hline Clozapine & Tablets & $2.7 \%$ & $\begin{array}{l}\text { Cardiotoxicity, fever, chills, bodyache, flu symptoms, } \\
\text { mouth-throat ulcers, cough, sore throat, rapid heart rate, } \\
\text { rapid and shallow breathing. }\end{array}$ & (Cole et al. 2009) \\
\hline Methadone & Tablets & $3.6 \%$ & $\begin{array}{l}\text { Respiratory depression, QT prolongation, lacrimation, } \\
\text { chilling, rhinorrhea, tachycardia, cramps, anorexia, } \\
\text { nausea, dilated pupils, fluching }\end{array}$ & $\begin{array}{l}\text { (Kung et al. 2008) (Minino } \\
\text { et al. 2002) }\end{array}$ \\
\hline Morphine & Injection & $3 \%$ & $\begin{array}{l}\text { Constipation, addiction, asphyxia, respiratory depression, } \\
\text { renal failure, slow heartbeat, increase in B.P. }\end{array}$ & (Haupt and Jeste 2006) \\
\hline Acetaminophen & Capsules & $1.5 \%$ & $\begin{array}{l}\text { dark urine, loss of appetite, jaundice, damage to liver } \\
\text { and death, difficulty in breathing, swelling of face and } \\
\text { lips }\end{array}$ & (Huismen et al. 2002) \\
\hline Ethanercept & $\begin{array}{l}\text { Syringe and subcutaneous } \\
\text { injection }\end{array}$ & $0.18 \%$ & $\begin{array}{l}\text { Injection site pain, erythema reaction, rheumatoid } \\
\text { arthritis, vestibular neuritis }\end{array}$ & (Orlando and Perkins 2002) \\
\hline Risperidone & Tablets & $1.6-1.7 \%$ & $\begin{array}{l}\text { Stroke, heart failure, pneumonia, irregular heartbeat, } \\
\text { seizure, white patches and sore in lips }\end{array}$ & (Holford 1986) \\
\hline Paclitaxel & Injectionand vials & $\begin{array}{l}0.01- \\
0.06 \%\end{array}$ & $\begin{array}{l}\text { Blurred vision, black stools, painful urination, ulcers, } \\
\text { sores, red spots on skin, urticaria }\end{array}$ & (Orlando and Perkins 2002) \\
\hline Paroxetine & Tablets & $0.9 \%$ & $\begin{array}{l}\text { Bone pain, serious ventricular arrhythmias, agitation, } \\
\text { hallucinations, tremors, increase in muscle tone }\end{array}$ & (Thisted et al. 1986) \\
\hline Rofecoxib & Tablets & $2-3 \%$ & $\begin{array}{l}\text { Increased arrhythmias, abdominal pain, tenderness, or } \\
\text { discomfort, nausea, blood while vomiting, bloody, black, } \\
\text { or tarry stools, unexplained weight gain, swelling or } \\
\text { water retention, fatigue or lethargy, skin rash, itching, } \\
\text { yellowing of skin or eyes, flu-like symptoms, or unusual } \\
\text { bruising or bleeding. }\end{array}$ & (Krumholz et al. 2007) \\
\hline Warfarin & Tablets & $1.2-2.3 \%$ & $\begin{array}{l}\text { Fatal bleeding, stroke, heart attack, abdominal pain, } \\
\text { crawling, numbness, increase in menstrual flow, vaginal } \\
\text { bleeding, paralysis, shortness of breath, diarrhea, skin } \\
\text { blisters, hemorrhage, necrosis, purple toe syndrome }\end{array}$ & (Holbrook et al. 2005) \\
\hline Celecoxib & Capsules & $1 \%$ & $\begin{array}{l}\text { Risk of GI ulcerations, bleeding perforations, coronary } \\
\text { artery disorder, cellulitis, angina pectoris, deep thrombo } \\
\text { phlebritis, myocardial infarction, pneumonia, unstable } \\
\text { angina }\end{array}$ & (Halpern 2005) \\
\hline Atorvastatin & Tablets & 37 deaths & $\begin{array}{l}\text { Liver damage, loss of appetite, allergic pruritis, muscles } \\
\text { and joint pain, tendon problems, tiredness, jaundice }\end{array}$ & (Gaudreault et al. 1982) \\
\hline Misoprostol & Tablets & $5-6 \%$ & $\begin{array}{l}\text { Abortion, miscarriage, Gl bleeding, multi organ failure, } \\
\text { acute pain, haemodynamic instability, oesophageal } \\
\text { necrosis, cardiac arrest, resuscitation efforts, birth defects }\end{array}$ & (Fu et al. 1998) \\
\hline Thalidomide & Capsules & $10 \%$ & $\begin{array}{l}\text { Somnolence, haematuria, urticaria, asthenia, pulmonary } \\
\text { embolism, heart failure, bradycardia, tachycardia, cardiac } \\
\text { arryhmias, deep vein thrombosis, seizures, orthostatic } \\
\text { hypotension, birth defects (phocomelia) }\end{array}$ & (Ito et al. 2010) \\
\hline Insulin & $\begin{array}{l}\text { Only in old patients injections } \\
\text { subcutaneous insulin pump } \\
\text { transdermal intranasal }\end{array}$ & $\begin{array}{l}\text { Not } \\
\text { available }\end{array}$ & $\begin{array}{l}\text { Hypoglycemia (may result fatal if severe), low BP, } \\
\text { irritability, fast heartbeat, convulsions, blurred visions }\end{array}$ & (FDA 2009) \\
\hline Aspirin & Tablets & $25 \%$ & $\begin{array}{l}\text { Excess acid secretion, stomach cramps, haemorrhage, } \\
\text { bronchospasm, hepatitis interstitial, nephritis, } \\
\text { inflammation of skin, allergic, abnormal liver } \\
\text { functioning, clotted organs and tissues }\end{array}$ & (Schluter 1989) \\
\hline $\begin{array}{l}\operatorname{cox} 2 \\
\text { inhibitors }\end{array}$ & Tablets & 3- $3.9 \%$ & $\begin{array}{l}\text { Myocardial infarction, fatal stroke, death from vascular } \\
\text { events, hypertension, congestive heart failure, ulceration, } \\
\text { bleeding from stomach, coronary artery blockage }\end{array}$ & $\begin{array}{l}\text { (He et al. 2005; Solomon } \\
\text { et al. 2004) }\end{array}$ \\
\hline
\end{tabular}


Table 2 List of drugs causing ADRs (Continued)

\begin{tabular}{|c|c|c|c|c|}
\hline Ciprofloxacin & $\begin{array}{l}\text { Tablets- extended release } \\
\text { tablets oral suspension }\end{array}$ & $0.65-1.2 \%$ & $\begin{array}{l}\text { High BP, angina, paroxysmal supraventicular tachycardia, } \\
\text { prolonged QT interval, blood clot in brain, hepatitis, } \\
\text { interstitial nephritis, migraine }\end{array}$ & (Carlo and Francesco 1978) \\
\hline Gentamicin & $\begin{array}{l}\text { Tablets, cream, ointments, } \\
\text { injectable }\end{array}$ & - & $\begin{array}{l}\text { Severe kidney failure, nerve damage, permanent hearing } \\
\text { loss, agitation, stomach pain, blood in urine, chest pain, } \\
\text { stroke, coma, hallucinations, mental changes }\end{array}$ & (Carlo and Francesco 1978) \\
\hline Imipramine & Tablets & $\begin{array}{l}0.001 \% \\
\text { only on } \\
\text { overdose }\end{array}$ & $\begin{array}{l}\text { Slow heartbeat, abnormal heart rhythm, Low blood } \\
\text { pressure, Inability to have an erection, hallucinations, } \\
\text { involuntary quivering, difficult urination, nervous, } \\
\text { confused, heart burn, diarrhea }\end{array}$ & (Delini et al. 2007) \\
\hline Fluoxetine & Capsules, tablets, liquids & $\begin{array}{l}0.014- \\
0.62 \%\end{array}$ & $\begin{array}{l}\text { Severe blistering, peeling and red skin rash, uneven } \\
\text { heartbeats, tremors, overactive reflexes, hallucination } \\
\text { and seizures }\end{array}$ & (Michael and Ma 2006) \\
\hline Tetrabenazine & Tablets & $\begin{array}{l}0.5 \% \text { only } \\
\text { on } \\
\text { overdose }\end{array}$ & $\begin{array}{l}\text { Neuroleptic malignant syndrome, irregular heartbeats, } \\
\text { parkinsonism, tardive dystonia, stroke sometimes, purple } \\
\text { patches, mental changes, tightness in chest, shortness } \\
\text { of breath, sore throat }\end{array}$ & (Jankovic and beach 1997) \\
\hline Propofol & Injectable & $0.6-1.2 \%$ & $\begin{array}{l}\text { Severe hypotension, bradycardia, pulmonary edema, } \\
\text { systole, cardiac arrest, ventricular arrhythmias, respiratory } \\
\text { acidosis, dysponea, bronchospasm }\end{array}$ & (Douketis et al. 2007) \\
\hline
\end{tabular}

\section{Anecdotal reporting}

This kind of reporting comes through reports of individual doctors when a patient suffers from the particular effect.

\section{Impulsive reporting system}

This method is considered as the most efficient method. Mostly, all ADR reporting programmes follow this method. Here, the effects are recorded spontaneously. With this method, both unusual and acute ADRs can be focused on and monitored (Naranjo and Busto 1981).

\section{Intensive monitoring studies}

Health care members continuously watch the patients and record all the events observed when a drug or different drugs are administered. In this, defined groups of patients are screened to detect ADRs. The main disadvantage of these studies is that the population includes the minimum patients and each patient is studied for the concise period of time. Special investigations can be performed if statistical screening is incorporated in this study method (Naranjo and Busto 1981; Nebeker and Barach 2008).

Table 3 Records of banned drugs

\begin{tabular}{|c|c|c|c|c|c|}
\hline $\begin{array}{l}\text { Marketed } \\
\text { drug }\end{array}$ & Dosage form & $\begin{array}{l}\text { Banned } \\
\text { date }\end{array}$ & Reasons & $\begin{array}{l}\text { Death } \\
\text { occurred }\end{array}$ & Ref \\
\hline $\begin{array}{l}\text { Terfenadine } \\
\text { (Seldane) }\end{array}$ & Tablets & $\begin{array}{l}\text { February } \\
1998\end{array}$ & $\begin{array}{l}\text { Irregular heartbeat, stomach pain, light coloured stools, } \\
\text { yellowing of eyes or skin, fainting, dizziness, abdominal } \\
\text { discomfort, dry skin or itchiness, prolongation of QT interval, } \\
\text { headache, benign prostatic hypertrophy, acute hepatitis, } \\
\text { cholestatic hepatitis, jaundice, hepatic dysfunction }\end{array}$ & $0.9-1.2 \%$ & (Ito et al. 2010) \\
\hline $\begin{array}{l}\text { Mibefradil } \\
\text { (Posicor) }\end{array}$ & Tablets & June 1998 & $\begin{array}{l}\text { Leg edema, hypertension, chronic angina, rhinitis, leg edema, } \\
\text { heart stroke, headache, abdominal pain, light headedness, } \\
\text { dyspepsia }\end{array}$ & $\begin{array}{l}123 \text { death } \\
\text { in } 1 \text { year }\end{array}$ & $\begin{array}{l}\text { (Chyka et al. } \\
\text { 2007) }\end{array}$ \\
\hline $\begin{array}{l}\text { Astemizole } \\
\text { (Hismanal) }\end{array}$ & Tablets, capsules & July 1999 & $\begin{array}{l}\text { Heart problems, death, cardiac arrest, QT prolongation, } \\
\text { Torsades de pointes, ventricular arrhythmias, cardiac } \\
\text { arrhythmias, bradycardia, hypotension }\end{array}$ & $1-2 \%$ & $\begin{array}{l}\text { (Minino et al. } \\
\text { 2002) }\end{array}$ \\
\hline $\begin{array}{l}\text { Cisapride } \\
\text { (Populsid) }\end{array}$ & $\begin{array}{l}\text { Tablets, oral suspension, } \\
\text { capsules, medi-melt tab- } \\
\text { lets, injections }\end{array}$ & $\begin{array}{l}\text { January } \\
2000\end{array}$ & $\begin{array}{l}\text { Fast heartbeat, convulsions, irregular heartbeat, QT } \\
\text { prolongations, torsades de pointes, cardiac arrest, sudden } \\
\text { death renal failure, ventricular arrhythmias }\end{array}$ & $\begin{array}{l}80 \text { deaths } \\
\text { during } \\
\text { clinical trial }\end{array}$ & $\begin{array}{l}\text { (Solomon et al. } \\
\text { 2004) }\end{array}$ \\
\hline Rofecoxib & Tablets & $\begin{array}{l}\text { November } \\
2007\end{array}$ & $\begin{array}{l}\text { increased arrhythmias, abdominal pain, tenderness, or } \\
\text { discomfort, nausea, blood while vomiting, bloody, black, or } \\
\text { tarry stools, unexplained weight gain, swelling or water } \\
\text { retention, fatigue or lethargy, skin rash, itching, yellowing of } \\
\text { skin or eyes, flu-like symptoms, or unusual bruising or } \\
\text { bleeding. }\end{array}$ & $2-3 \%$ & $\begin{array}{l}\text { (He et al. 2005) } \\
\text { (Solomon et al. } \\
\text { 2004) }\end{array}$ \\
\hline
\end{tabular}


Table 4 Records of drugs withdrawn after ADRs observed in patient

\begin{tabular}{|c|c|c|c|c|}
\hline Marketed drug & Dosage form & Withdrawn due to & $\begin{array}{l}\text { Patient's } \\
\text { effected }\end{array}$ & References \\
\hline Gatifloxacin & Tablets, injectables & Causes hyperglycemia and liver damage & $1.2 \%$ & $\begin{array}{l}\text { (Carlo and Francesco } \\
\text { 1978) }\end{array}$ \\
\hline Phenylpropanolamine & $\begin{array}{l}\text { Microcapsules, tablets, sustained } \\
\text { release tablets }\end{array}$ & Increased risk of stroke & $0.01 \%$ & $\begin{array}{l}\text { (Gaudreault et al. } \\
\text { 1982) }\end{array}$ \\
\hline $\begin{array}{l}\text { Propoxyphene } \\
\text { (Darvon) }\end{array}$ & Capsule, tablet film coated & Caused fatal heart rhythm abnormalities & $0.8 \%$ & (Delini et al. 2007) \\
\hline Sibutramine & Capsule & Increased cardiovascular risk & $0.2 \%$ & (Schluter 1989) \\
\hline Tegaserod & Tablets & Causes increased risk of heart attack & $0.6 \%$ & (Marx 2006) \\
\hline $\begin{array}{l}\text { Nimesulide (below } \\
13 \text { years age) }\end{array}$ & $\begin{array}{l}\text { Tablets, oral suspension, gel, } \\
\text { suppositories }\end{array}$ & Caused life threatening hepatotoxic effects & $1.3 \%$ & $\begin{array}{l}\text { (Gaudreault et al. } \\
\text { 1982) }\end{array}$ \\
\hline Cisapride & $\begin{array}{l}\text { Tablets, oral suspension, capsules, } \\
\text { medi-melt tablets, injections }\end{array}$ & Risk of cardiac arrhythmias & $0.03 \%$ & (Solomon et al. 2004) \\
\hline Thalidomide & Capsules & Risk of teratogenicity & $6-8 \%$ & (Ito et al. 2010) \\
\hline Temafloxacin & Tablets & $\begin{array}{l}\text { Caused allergic reactions and } \\
\text { haemolyticanaemia }\end{array}$ & $0.002-0.04 \%$ & (Delini et al. 2007) \\
\hline Alpidem & Tablet- film coated, & Proved to be hepatotoxic & $0.6 \%$ & $\begin{array}{l}\text { (Gaudreault et al. } \\
\text { 1982) }\end{array}$ \\
\hline Tolrestat (Alredase) & Withdrawn not available & Proved as severe hepatotoxic agent & Not available & $\begin{array}{l}\text { (Schonthal et al. } \\
\text { 2003) }\end{array}$ \\
\hline Terfenadine (Seldane) & Tablet withdrawn & Caused cardiac arrhythmias & $1.2 \%$ & $\begin{array}{l}\text { (Orlando and Perkins } \\
\text { 2002) }\end{array}$ \\
\hline Mibefradil (Posicor) & Tablets & Reported to cause drug interaction & $\begin{array}{l}123 \text { death in } \\
1 \text { year }\end{array}$ & (Holford 1986) \\
\hline Tolcapone & Tablets & Hepatotoxic in nature & Not available & (Delini et al. 2007) \\
\hline Astemizole & Tablet & Interaction with other drugs & $0.2 \%$ & (Holbrook et al. 2005) \\
\hline Troglitazone & & Showed to be hepatotoxic & $0.009 \%$ & (Solomon et al. 2004) \\
\hline Cisapride & $\begin{array}{l}\text { Tablets, oral suspension, capsules, } \\
\text { medi-melt tablets, injections }\end{array}$ & Caused cardiac arrhythmias & $\begin{array}{l}80 \text { deaths } \\
\text { during clinical } \\
\text { trial }\end{array}$ & (Solomon et al. 2004) \\
\hline Trovafloxacin & Oral tablets & Liver failure cases reported & $0.4 \%$ & (Ito et al. 2010) \\
\hline Cerivastatin & Tablets & Caused rhadomyolysis & Not available & (Chyka et al. 2007) \\
\hline Rofecoxib (Vioxx) & Tablets & Myocardial infarction were reported & $2-3 \%$ & $\begin{array}{l}\text { (He et al. 2005) } \\
\text { (Solomon et al. 2004) }\end{array}$ \\
\hline Valdecoxib (Bextra) & Tablets & Heart attack and stroke occurred & $0.8 \%$ & (Halpern 2005) \\
\hline Tegaserod (Zelnorm) & Tablets & $\begin{array}{l}\text { Cardiovascular ischemic events occurred } \\
\text { followed by heart attack and stroke }\end{array}$ & $0.03 \%$ & (Marx 2006) \\
\hline Aprotinin & Tablets, injection & Death occurred & Not available & (Marx 2006) \\
\hline Thioridazine & Tablets & Cardio toxicity occurred by its use & Not available & (Marx 2006) \\
\hline Sibutramine & Capsule & Cardiovascular risk increases by its use & $0.2 \%$ & $\begin{array}{l}\text { (Schonthal et al. } \\
\text { 2003) }\end{array}$ \\
\hline
\end{tabular}

\section{Contingent studies}

In these studies, patients administering similar medicines are identified, and their events are recorded. Major drawbacks of this method are that minimum patients are included and no control group is present for comparison. The contingent examinations are too expensive, and these investigations are difficult to perform on newly marketed drugs (Nissen and Wolski 2007).

\section{Case-control studies (Retrospective Studies)}

In these studies, patients who have illness or disease due to the use of a drug are investigated to check if they have taken the drug. These patients are then compared with a matched control group that is similar in confounding factors but do not possess the adverse events or illness. This is a useful method in determining whether the drug has caused the adverse event or not. However, by this 
Table 5 Details required for reporting ADR events

\begin{tabular}{|c|c|c|c|}
\hline $\begin{array}{l}\text { Elements in } \\
\text { ADR reporting }\end{array}$ & Necessary information & Others & References \\
\hline $\begin{array}{l}\text { What should } \\
\text { be reported }\end{array}$ & Adverse reactions of the drug, suspected drug's details, patient's information & $\begin{array}{l}\text { Medications overdose, } \\
\text { pharmaceutical defect, drug } \\
\text { interactions }\end{array}$ & $\begin{array}{l}\text { Goldman } \\
1998\end{array}$ \\
\hline $\begin{array}{l}\text { Who can } \\
\text { report }\end{array}$ & $\begin{array}{l}\text { medical practitioners or health care professionals, doctors, nurses, pharmacists, } \\
\text { assistants, pharmaceutical technicians, pharmaceutical assistants, clinical officers } \\
\text { and other health care providers }\end{array}$ & $\begin{array}{l}\text { Manufacturers, all government } \\
\text { and private hospital's health } \\
\text { center }\end{array}$ & $\begin{array}{l}\text { Palaian et al. } \\
2006\end{array}$ \\
\hline $\begin{array}{l}\text { When it can be } \\
\text { reported }\end{array}$ & Any adverse reactions if noticed should be reported as soon as possible. & - & $\begin{array}{l}\text { Ravi Shankar } \\
\text { et al. } 2010\end{array}$ \\
\hline How to report & Through completely filled yellow card form & - & $\begin{array}{l}\text { Ravi Shankar } \\
\text { et al. } 2010\end{array}$ \\
\hline $\begin{array}{l}\text { Where it can } \\
\text { be reported }\end{array}$ & $\begin{array}{l}\text { Fully filled completely ADR form should be submitted to pharmacovigilance } \\
\text { center }\end{array}$ & - & $\begin{array}{l}\text { Palaian et al. } \\
2006\end{array}$ \\
\hline
\end{tabular}

method, new ADRs cannot be identified (Parthasarathi et al. 2007).

\section{Case cohort studies}

These studies include both prospective cohort study and retrospective case-control studies; in other words, it is the combination of both the studies (Pearson et al. 1994).

\section{Record linkage}

In this method, all the records such as prescription records, patient records and hospital records are studied to identify the illness with drugs.

\section{Meta analysis}

It is a quantitative examination of two or more independent studies to determine the overall effect and to describe reasons in variation of study results (Prosser and Kamysz 1990).

\section{Utilitization of resident's statistics}

If a drug-induced event is very frequent and if suspicions arise for them, case-control and experimental cohort studies shall be initiated (Rao 2010).

\section{Roles of pharmacovigilance in monitoring ADRs}

Many incidents occurred that caused the need of laws and regulations regarding the safe use of drugs. After rofecoxib withdrawal from the European market, the FDA rules on post-market surveillance were criticized and a new system of pharmacovigilance was introduced that provided information on identified risks (Palaian et al. 2006; Rawlins and Thompson 1981; Yadav 2008).

Throughout the early post-marketing period, the product might be used in different groups of people from those used in clinical trials and much larger populations might be exposed in a relatively short time. The postmarketing product is required to develop new information, which can focus on the benefits as well as risks of the product (Arnott et al. 2012). Pharmacovigilance produces detailed information of marketed products to ensure their safe use.

The impressive pharmacovigilance planning can reduce the adverse events of drugs in patients. The most important method used in pharmacovigilance is to collect information on a drug when it is in the pre-marketing phase is by conducting a clinical trial. This study design is not optimum to determine the ADRs of the drug. Because in this approach limited numbers of patients participate and it is not necessary that the patients resemble the population in which the drug is to be used (Arora 2008; Bahri and Tsintis 2005), it becomes impossible to understand the mechanism and consequence of the drug in these groups. Some methods that can be helpful in the detection as well as the prevention of suspected ADRs are listed as follows.

Different study designs are included for proper pharmacovigilance study:

a. Descriptive studies:

Descriptive studies are conducted to obtain the outcome rate of drug use events in a specific population. These studies include the data of adverse events that occurred in diseased patients. Another factor included is the drug utilization study (Biswas and Biswas 2007; Biswas 2008). These studies provide data on the specific groups of patients such as children, elderly or patient with renal or hepatic dysfunction. With these data study rates of adverse events can be reported.

b. Analytical studies:

Analytical studies are performed to study related outcomes of the exposure to the drug. They can take the form of observational as well as interventional/experimental studies. There are four main types of analytical studies namely ecological, cross-sectional, cohort and case-control (Brewer and Colditz 1999). 
c. Observational studies:

Observational studies provoke aspects of drug effectiveness in patients during treatment. This is in contrast with experiments, such as randomized controlled trials, where each subject is indiscriminately allocated to a treatment group or a control group (Ciorciaro et al. 1998; Jeetu and Anusha 2010; Joshi and Sapatnekar 2008).

\section{Methods in pharmacovigilance for monitoring of ADR Passive surveillance}

Spontaneous reports The spontaneous reporting systems were developed after the thalidomide incident. The aim of this spontaneous reporting system is to regulate and control the safety of drugs. This system is applied in the collection of post-marketing information on safety of drugs and identification of safety signals. Consequently, this system is used in the identification of signals of new, rare and serious ADRs of drugs. This system makes it easier for physicians, patients and pharmacists to report suspected ADRs to the pharmacovigilance centre (Herdiero et al. 2005; Olsson 2008; Rahman et al. 2007). The pharmacovigilance centre collects all these reports and informs the stakeholders about the new reported ADRs. By this method, we can monitor all drugs in the market throughout their lifecycles (Ravindra and Vishal 2011); (Surendra et al. 2010).

Case series The case series are applied in developing a hypothesis between post-marketing drugs and its outcome (Faich 1996).

\section{Stimulated reporting}

The stimulated reporting system encourages and facilitates health professionals to report ADRs in specific situations. It is very useful in generating adverse events of drugs online (Gerritsen et al. 2011). It is effective in generating spontaneous reports of adverse events of drugs identified during the post-marketing phase. This system can assist in minimizing events by linking stimulated reporting with early post-marketing phase (Gupta 2010).

\section{Active surveillance}

Active surveillance includes a pre-organized process to find out more serious adverse events, including the additional efforts to find the adverse reactions. Risk management programme is followed in this process, and more detailed information on individual adverse event reports can be obtained compared with passive surveillance (Panos et al. 2004; Harmark and Van Grootheest 2008; Surendra et al. 2010; Muthiah et al. 2012; Lobo et al. 2013; Kshirsagar et al. 2011).

\section{Comparative observation studies}

To test a hypothesis, a study has to be performed. These are the key events to evaluate the adverse events. The study can be conducted using different methods, which can be retrospective and perspective. Major types of these studies are cross-sectional studies, case-control studies and cohort studies (Bates et al. 1995). Cross-sectional studies are conducted for ecological analysis. These are helpful in examining the prevalence of any disease at one time point. These studies are helpful to provide information between exposure of the drug and outcome in the ecological analysis.

Case-control study can easily identify the adverse events of drugs. The ADRs are determined by comparing the two distinctive groups. Case-control studies are useful when they are aimed to investigate adverse event in different groups. It is helpful in determining the absolute incidence rate of the adverse events.

Cohort studies provide data that has been collected in a routine fashion. This study can also be used to examine safety issues in specific populations such as children and patients with co-morbid conditions (Gor and Desai 2008; Hussein et al. 1999).

\section{Earmarked clinical examinations}

After pre-approved clinical trials, if sufficient risks are identified, further clinical studies are done to find or evaluate the mechanism of action for the identified adverse reactions. Pharmacokinetic and pharmacodynamic studies are applicable in determining the particular dosing, which can cause enhanced uncertainty of adverse effects in patients. Genetic testing can also be helpful in knowing which group of patients might be at an increased risk of adverse reactions. Children, elderly and patients with renal conditions might metabolize drugs in a different manner compared with patients enrolled or included in clinical trials. By these investigations events of particular interest are focused and used to determine or quantify the magnitude of the risk (Surendra et al. 2010).

Thus, all of the above steps are linked with adverse event monitoring studies. Consequently, good safety profile of drug can be established and further suspected adverse events can be minimized and prevented by incorporating the pharmacovigilance methods for adverse drug reactions.

\section{Conclusions}

ADRs have a perspective to provoke harmful effects in patients. Health-care workers and pharmacovigilance constrain being more conscious of perceive the ADRs in the patient. In conclusion, this study can be useful for physician to identify the ADRs in patients by applying above mentioned methods. 


\section{Competing interests}

The authors declare that they have no competing interests.

\section{Authors' contributions}

RKS and RY carried out literature review and draft the manuscript. PP, AR and SC participated in collection of data and arranged in tabular form. All authors read and approved the final manuscript.

\section{Received: 6 June 2014 Accepted: 17 November 2014}

\section{Published: 26 November 2014}

\section{References}

Aeries N (1995) Consumer reporting of ADRs. WHO Drug Information 14:211-215

Arnott J, Hesselgreaves H, Nunn AJ, Peak M, Pirmohamed M (2012) What can we learn from parents about enhancing participation in Pharmacovigilance? British J Clin Pharmacol 78(2):312-322

Arora D (2008) Pharmacovigilance obligations of the pharmaceutical companies in India. Indian J Pharmacol 40:13-16

Bahri P, Tsintis P (2005) Pharmacovigilance-related topics at the level of the International Conference on Harmonisation (ICH). Pharmacoepidemiol Drug Saf 14:377-387

Bates DW, Cullen DJ, Laird N (1995) Incidence of adverse drug events and potential adverse drug events. JAMA 274:29-34

Beard K (1992) Adverse reactions as a cause of hospital admission in the aged. Indian J Pharmacol 2:356-357

Biswas P (2008) Pharmacovigilance safety matters. Indian J Pharmacol 7613(40):1-3

Biswas P, Biswas A (2007) Setting standards for proactive pharmacovigilance in India: The way forward. Indian J Pharmacol 39:124-128

Brewer T, Colditz GA (1999) Postmarketing surveillance and adverse drug reactions: current perspectives and future needs. JAMA 281:824-829

Carlo T, Francesco S (1978) Ototoxicity of tobramycin, gentamicin, amikacin and sisomicin. J Antimicrob Chemother 4:73-83

Chyka PA, Erdman AR, Christianson G, Wax PM, Booze LL, Manoguerra AS, Caravati (2007) Salicylate poisoning: an evidence-based consensus guideline for out-of-hospital management. Clin Toxicol 45(2):95-131

Ciorciaro C, Hartmann K, Kuhn M (1998) Differences in the relative incidence of adverse drug reactions in relation to age, an evaluation of the spontaneous reporting system of SANZ. Journal Suisse de medicine 128:254-258

Classen DC, Pestotnik SL, Evans RS (1997) Adverse drug events in hospitalized patients. JAMA 277(4):301-306

Cole M, Proctor GB, Trigoboff E (2009) Adverse Drug Reaction Review: Evaluation of Concomitant Medications Effecting Blood Dyscrasias Associated with Clozapine. American Society of Health-System Pharmacists, Las Vegas December 6-10

Delini SA, Mikkelsen H, Angst J (2007) Therapeutic efficacy of antidepressants in agitated anxious depression-a meta-analysis of moclobemide studies. J Affect Disord 35(2):21-30

Doheny K (2009) Reports of adverse drug effects up. Web MD Health News 6:1-2

Douketis JD, Crowther M, Wells PS (2007) A review on propofol and its drug and food interactions. Arch Intern Med 45(10):167-176

Faich GA (1996) U.S. adverse drug reaction surveillance. Pharmacoepidemiol Drug Saf 5(6):393-398

FDA (2009) Early Communication about Safety of Lantus (insulin glargine). US Food and Drug Adminstration, Silver Spring, MD

Fu H, Darroch JE, Henshaw SK, Kolb E (1998) Measuring the extent of abortion underreporting in the 1995. Fam Plann Perspect 30:128-133, 138

Gaudreault P, Temple AR, Lovejoy FH (1982) The relative severity of acute versus chronic salicylate poisoning in children: a clinical comparison. Pediatrics 70(4):566-569

Gerritsen R, Faddegon H, Dijkers F, VanGrootheest K, Van Puijenbroek E (2011) Effectiveness of pharmacovigilance training of general practitioners: a retrospective cohort study in the Netherlands comparing two methods. Drug Saf 34:755-762

Goldman SA (1998) Limitations and strengths of spontaneous reports data. Clinical Therapeutic 4:40-44

Gor AP, Desai SV (2008) Adverse drug reaction in the in patients of medicine department of a rural tertiary care teaching hospital and influence of pharmacovigilance in reporting ADR. Indian J Pharmacol 40(1):37-40

Gupta Y (2010) Ensuring patient safety- launching the new pharmacovigilance programme of india. Pharma Times 42(8):234-289
Gupta P, Udupa A (2011) Adverse drug Reaction Reporting and pharmacovigilance: knowledge, attitudes and perceptions amongst resident doctors. J Pharm Sci Res 1459(2):1064-1069

Hall M, Mc Cormack P, Arthurs N, Feely J (1995) The spontaneous reporting of ADRs by nurses. British J ClinPharmacol 3:173-175

Halpern GM (2005) COX-2 inhibitors: a story of greed, deception and death. Inflammo Pharmacology 13(4):419-425

Hampton T (2005) Experts point to lessons learned from controversy over rofecoxib safety. JAMA 293:413-414

Harmark L, Van Grootheest AC (2008) Pharmacovigilance: methods, recent developments and future perspective. European J ClinPharmacol 64(6):743-752

Haupt M, Jeste D (2006) Mortality in elderly dementia patients treated with risperidone. J ClinPsychopharmacol 26(6):566-570

He Q, Luo X, Jin W, Huang Y, Reddy MV (2005) Celecoxib and a novel COX-2 inhibitor ON09310 up regulate death receptor 5 expression via GADD153/ CHOP. Inflammo Pharmacology 13(4):419-425

Herdiero MT, Figueiras A, Polonia J (2005) Physians attitudes and adverse drug reaction reporting: a case control study in Portugal. Drug Saf 28(9):825-833

Holbrook AM, Pereira JA, Labiris R, McDonald H, Douketis JD, Crowther M, Wells PS (2005) Systematic overview of warfarin and its drug and food interactions. Arch Intern Med 165(10):1095-1106

Holford NH (1986) Clinical pharmacokinetics and pharmacodynamics of warfarin understanding the dose-effect relationship. Clin Pharmacokinet 11(6):483-504

Hornbuckle K, Wu HH, Fung MC (1999) Evaluation of spontaneous adverse event reports by primary reporter - a 15-year review (1983 to 1997). Drug Inf J 33:1117-1124

Huismen C, Ferreira CG, Broker LE (2002) Paclitaxel triggers cell death primarily via caspase-independent routes in the non-small cell lung cancer cell line. Clin cancer Res 8(2):596-606

Hussein G, Bleidt B, Belding B (1999) Recognition evaluation and reporting of adverse drug reactions. Clin Res Regul Aff 16(3):91-107

Ito T, Ando H, Suzuki T, Ogura T, Hotta K, Imamura Y, Yamaguchi Y, Handa H (2010) Identification of a primary target of thalidomide teratogenicity. Science 327(5971):1345-1350

Jankovic J, beach J (1997) Long term effects of tetrabenazine in hyperkinetic movement disorders. Neurology 48(2):358-362

Jeetu G, Anusha G (2010) Pharmacovigilance: a worldwide master key for drug safety monitoring. Journal Young Pharm 2(3):315-316

Joshi SR, Sapatnekar SM (2008) The importance of pharmacovigilance. Geneva: World Health Organization, Pharmacovigilance in India: how safe are the new drugs? How sure are we? J Assoc Physicians Ind 56(8):933-934

Juntti PL, Neuvoren PJ (2002) Drug related deaths in a university central hospital. Eur J ClinPharmacol 58:479-482

Karch FE, Lasagna L (1997) Towards the operational identification of adverse drug reactions. Clin Pharmacol Ther 21:247-254

Kessler DA (1993) Introducing Med Watch, using FDA form 3500, a new approach to reporting medication and device adverse effects and product problems. JAMA 269:2765-2778

Krumholz HM, Ross JS, Presler AH (2007) What have we learnt from Vioxx? Br Med J 334:120-123

Kshirsagar N, Ferner R, Figueroa BA, Ghalib H, Lazdin J (2011) Pharmacovigilance methods in public health programmes: the example of miltefosine and visceral leishmaniasis. Trans R Soc Trop Med Hyg 105:61-67

Kung HC, Hoyert DL, Xu JQ, Murphy SL (2008) Increase in poisoning and methadone related effects; National Center for Health Statistics. Natl Vital Stat Rep 56(10):8-15

Lazarou J, Pomeranz BH, Corey PN (1998) Incidence of adverse drug reactions in hospitalized patients-a meta-analysis of prospective studies. JAMA 2:1200-1205

Lisa A, Ladewski SM, Belknap JR, Nebeker OS (2003) Dissemination of information on potentially fatal adverse drug reactions of drugs from 2000 to 2002: first results from the research on adverse drug events and reports project. J ClinOncol 21(20):3859-3866

Livio F, Renard D, Buclin T (2012) Pharmacovigilance, a review. Med Suisse 8:116-119

Lobo A, Germana M, Gerley J (2013) Adverse drug reaction monitoring; support for pharmacovigilance at a tertiary care hospital in northern Brazil. BMC Pharmacol Toxicol 78(3):1-7

Marx J (2006) Rosen's Emergency Medicine: Concepts and Clinical Practice. Mosby Inc Mosby/Elsevier, Maryland Heights, Missouri, p 2242 
Michael S, Ma L (2006) Fluoxetine and suicide rates suicide and the economy. J Pub Med 3(11):501-503

Minino AM, Anderson RN, Fingerhut LA, Boudreault MA, Warner M (2002) Deaths: injuries. Natl Vital Stat Rep 54(10):1-20

Mishra H, Kumar V (2013) Pharmacovigilance: current scenario in a tertiary care teaching Medical College in North India. Journal Pharmacovigilance 1(2):1-4

Mohammed A (2012) Analysis of multiple risks involving the use of IV fentanyl. Patient Safe Advis 9(4):122-129

Moore N (2001) The role of the clinical pharmacologist in the management of ADRs. Drug Saf 24(1):1-7

Murphy BM, Frigo LC (1993) Development implementation and results of a successful ultidisciplinary adverse drug reaction reporting Program in a University Teaching Hospital. Hospital Pharm 28:1199-1240

Muthiah NS, Elumalai M, Murali NP (2012) HazraRamsundar: pharmacovigilance: a tool for health safety- review article. Indian J Multidiscip Dent 2(1):374-376

Naranjo CA, Busto U (1981) A method for estimating the probability of adverse drug reactions. Clin Pharmacol Ther 30:239-245

Nebeker JR, Barach P (2008) Clarifying adverse drug events, a clinicians view. Ann Intern Med 12:87-112

Nissen SE, Wolski K (2007) Effect of rosiglitazone on the risk of myocardial infarction and death from cardiovascular causes. N Engl J Med $356: 2457-2471$

Olsson S (2008) Pharmacovigilance training with focus on India. Ind J Pharmacol 40(7):28-30

Orlando M, Perkins CL (2002) Pretreatment with paclitaxel enhances apo-2 ligand/tumor necrosis factor-related apoptosis-inducing ligand-induced apoptosis of prostate cancer cells by inducing death receptors 4 and 5 protein levels. Clin cancer Res 8(2):596-606

Palaian S, Mishra P, Shankar PR, Dubey AK, Bista D, Almeida R (2006) Safety monitoring of drugs- where do we stand? Kathmandu Univ Med J 4(13):119-120

Panos T, Sintis P, La Mache E (2004) CIOMS and ICH initiatives in pharmacovigilance and risk management overview and implications European agency for the evaluation of medicinal products. London, United Kingdom Drug Safety 27(8):509-517

Parthasarathi G, Karin Nyfort H, Nahata MC (2007) Adverse Drug Reactions. A Textbook of Clinical Pharmacy Practice Essentials Concepts and Skills, vol 76 University Press, Hyderabad, pp 84-102

Pasero C (2005) Fentanyl for acute pain management. J Perianesth Nurs 20 (4):279-284

Pearson TF, Pittman D, Longley JM, Grapes T, Vigliotti DJ, Mullis SR (1994) Factors associated with preventable adverse drug reactions. Am J Hosp Pharm 51:2268-2271

Peng PW, Sandler AN (1999) A review of the use of fentanyl analgesia in the management of acute pain in adults. Anesthesiology 90(2):576-599

Prommer E (2009) The role of fentanyl in cancer-related pain. J Palliat Med 12 (10):947-954

Prosser TR, Kamysz PL (1990) Multidisciplinary adverse drug reaction surveillance program. American J Hosp Pharm 47:1334-1339

Purdue Pharma L.P. Stamford, CT (2009) 06901-3431 2010 U.S. Patent Numbers $5,508,042 ; 6,488,963 ; 7,129,248 ; 7,674,799 ; 7,674,800$ and 7,683,072

Rahman SZ, Khan RA, Gupta V, Uddin M (2007) Pharmacoenvironmentology - a component of pharmacovigilance. Environmental Health 56(20):38-42

Rao HP (2010) Reporting of adverse drug reactions by consumers: rationale and potential. Pharmbit. Am J Hosp Pharm 22(20):110

Ravi Shankar P, Subish P, Mishra P, Dubey AK (2006) Teaching pharmacovigilance to medical students and doctors. Indian J Pharmacol 38(5):316-319

Ravi Shankar P, Subish P, Mishra P, Dubey AK (2010) Teaching Pharmacovigilance to Medical students and doctors. Educational Forum 38(5):37-379

Ravindra A, Vishal B (2011) Pharmacovigilance: an overview. Int J Res Pharmacy Chemistry 1(40):968-969

Rawlins MD, Thompson JW (1981) Mechanisms of Adverse Drug Reactions. In: Textbook of Adverse Drug Reactions, 4th edn. Oxford University press, Oxford

Rehan HS, Vasudev K, Tripathi CD (2002) Adverse drug reaction monitoring: knowledge, attitude and practices of medical students and prescribers. Natl Med J India 15(1):24-25

Rishi RK, Patel RK, Bhandari A (2012) Opinion of physicians towards adverse drug reactions reporting results of pilot study. J Commun Nutr Health 1(1):25
Rohilla A, Singh N, Kumar V, Sharma MK, Dahiya A, Kushnoor A (2012) Pharmacovigilance: needs and objectives- review article. J Adv Pharm Technol Res 2(4):201-205

Santosh KC, Tragulpiankit P (2002) Pharmacovigilance: an overeview. Department of Pharmacy, Faculty of Pharmacy Mahidol University. Journal of Pharmaceutical Sciences 21:23-146

Schluter G (1989) Ciprofloxacin: toxicological evaluation of additional safety data. Am J Med 87(5):99-106

Schonthal AH, Chen TC, Hofman FM, Louie SG, Petasis NA (2003) Celecoxib analogs that lack. COX-2 inhibitory function: preclinical development of novel anticancer drugs. Expert Opin Investig Drugs 17(2):197-208

Shukla SS, Gidwani B, Pandey R, Rao SP, Singh V, Vyas (2012) A importance of pharmacovigilance in Indian pharmaceutical industry - review article. Asian Pharma Online 5:2231-5659

Solomon DH, Schneeweiss S, Glynn RJ, Kiyota Y, Levin R, Mogun H, Avorn (2004) Relationship between selective cyclooxygenase-2 inhibitors and acute myocardial infarction in older adults. American J 109:2068-2073

Surendra S, Dang A, Rataboli P (2010) Pharmacovigilance and Pharmaco epidemiology. Indian J Pharm Sci 72(1):96-102

Thisted B, Krantz T, Stroom J, Sorensen M (1986) Acute salicylate self-poisoning in 177 consecutive patients treated in ICU. Actaanaesthesiologica Scandinavica 31(4):312-316

Yadav S (2008) Status of adverse drug reaction monitoring and pharmacovigilance in selected countries. Indian J Pharmacol 40:4-9

doi:10.1186/2193-1801-3-695

Cite this article as: Sahu et al: Adverse drug reactions monitoring:

prospects and impending challenges for pharmacovigilance. SpringerPlus 2014 3:695

\section{Submit your manuscript to a SpringerOpen ${ }^{\odot}$ journal and benefit from:}

- Convenient online submission

$\checkmark$ Rigorous peer review

- Immediate publication on acceptance

- Open access: articles freely available online

- High visibility within the field

- Retaining the copyright to your article

Submit your next manuscript at springeropen.com 